\title{
Ulcer Protective and Ulcer Healing Activities of Aqueous and Methanolic Extracts of Leaves of Rumex Bequaertii De Wild (Polygonaceae) in Rats
}

\author{
Gilbert Ateufack (Corresponding author) \\ Laboratory of Animal Physiology and Phytopharmacology, Faculty of Science \\ University of Dschang P. O. box 67 Dschang Cameroon \\ Tel: 237-675-277-614Ｅ-mail: ateufack2000@yahoo.fr \\ Breuil R. Dongmo Feudjio \\ Laboratory of Animal Physiology and Phytopharmacology, Faculty of Science \\ University of Dschang P. O. box 67 Dschang Cameroon \\ E-mail: wwwdrostand@yahoo.fr
}

\begin{abstract}
William Nana Yousseu
Laboratory of Animal Physiology and Phytopharmacology, Faculty of Science

University of Dschang P. O. box 67 Dschang Cameroon

E-mail: nayouwyn@yahoo.fr
\end{abstract}

\begin{abstract}
Albert D. Atsamo
Laboratory of Animal Physiology, Faculty of Science

University of Yaoundé 1 P.O. Box 812 Yaoundé- Cameroon

E-mail: atsamoalbert@yahoo.fr
\end{abstract}

\begin{abstract}
Albert Kamanyi
Laboratory of Animal Physiology and Phytopharmacology, Faculty of Science

University of Dschang P. O. box 67 Dschang Cameroon

E-mail: bettykama@outlook.com
\end{abstract}


Received: February 4, 2015 Accepted: February 24, 2015

doi:10.5296/jbls.v6i2.7044

URL: http://dx.doi.org/10.5296/jbls.v6i2.7044

\begin{abstract}
The aqueous and methanolic extracts of Rumex bequaertii leaves were investigated for their ability to prevent and treated ulceration of the gastric mucosa in animal models.

For this, adult male rats three to four months old and weighing on average $180 \mathrm{~g}$ were used for both tests. The extracts were tested orally at doses of 125,250 and $500 \mathrm{mg} / \mathrm{kg}$, on ulcerations experimentally induced by $\mathrm{HCl} /$ ethanol and pylorus ligation (acute ulcer) and acetic acid (chronic ulcer).

These extracts showed protective and healing properties on ulcer induced models. A dose of $500 \mathrm{mg} / \mathrm{kg}$ of the two extracts inhibited ulceration induced by $\mathrm{HCl} / \mathrm{ethanol}$ by 98.86 and $91.59 \%$ respectively. With pyloric ligation, no significant variation of the volume of gastric juices, $\mathrm{pH}$ and gastric acidity was observed compared to the negative control rats. The aqueous extract alone at different doses presented a significant reduction of the ulceration surface resulting from chronic ulcer induced with acetic acid compared to the negative control group that received distilled water. For all three models of gastric ulcer induction used, the mass of mucus significantly increased in the groups that received the extracts. There was no significant variation in plasmatic nitric oxide (NO) concentration and gastric supernatant of rats treated with both extracts compared to both control groups. These results reveal that the healing process of the extracts is not achieved through the NO pathway. This process could be due to increase in mucus production and thus supports its traditional use of the plant
\end{abstract}

Keywords: Rumex bequaertii, Antiulcerogenic, Antiulcer

\title{
1. Introduction
}

The manufacture and clinical evaluation of herbal remedies and/or their constituents have made it possible to transform traditional medicine into a modern industry capable of making significant contributions in the delivery of healthcare (Ekpo et al., 2011). This revival of interest in plant derived drugs is mainly due to the current widespread belief that «green medicine» is safe, clinically effective, better tolerated by patients, less expensive and globally competitive (Pradhan et al., 2009; Joseph and Justin, 2011). In larger part of the developing world, plants or herbal products have forever played important roles in the treatment of inflammations, malaria, fever, liver and spleen disorders etc. In the treatment of ulcers, the choice of herbal products varies between regions and cultures. Gastroduodenal ulcer is a recurrent and chronic disease. Peptic ulcer results in an imbalance between aggressive factors (hydrochloric acid secretion, pepsin, Helicobacter pylori and frequent use of nonsteroidal anti-inflammatory drug) and gastric mucosal protective factors such as gastric mucosa, bicarbonate secretion, prostaglandin, nitric oxide and innate resistance of the mucosal (Tarnawski, 2005; Tulassay et Hersnzényi, 2010; Oliveira et al., 2011). The success of commercially available antiulcer drugs in the treatment of gastric ulcer is usually 
overshadowed by various side effects like helplessness, thrombocytopenia, arrhythmia gynecomasia, galactorrhea constipation and diarrhea etc. (Thirunavukkarasu et al., 2009; Malfertheiner et al., 2009). Due to these side effects, there is urgent need to find new antiulcerogenic and antiulcer chemical compounds with potentially less or no side effects. Medicinal plants have therefore been the main source of new drugs for the prevention or treatment of gastric ulcer (Borreli and Izzo, 2000; Rates, 2001).

Rumex bequaertii De Wild (Polygonaceae) is a herbaceous woody plant, reaching 1-2 m tall, with pale green or brown stem and very long and narrow leaves about $35 \mathrm{~cm}$. At maturity, it produces $(3 \mathrm{~mm})$ red, shiny berries and trines (Bernard Boullard, 2001). In Cameroon, as in South and East Africa, Rumex bequaertii is used in traditional medicine in the treatment of rheumatism, stomach upset, colic and abdominal pain, abscesses, malaria, boils, influenza, kwashiorkor, sciatica, cough, headache, and also as an anthelmintic and an antidote. An infusion of the roots is used to treat pneumonia, dysentery, venereal diseases and as a purgative (Chopra et al., 1986; Ishfaq et al., 2008; Focho et al., 2009). Rumex bequaertii has antiviral properties and inhibiting complement system (Cos et al., 2002ab), antihistaminic effects, anticholinergic or antibradykinic on the skin of rabbits in vivo (Aggarwal et al., 1986).

The present study was undertaken to determine the protective and healing potentials of aqueous and methanolic extracts of the leaves of Rumex Bequaertii using the following experimental gastric inducing ulcer methods: $\mathrm{HCl} / \mathrm{ethanol}$, pylorus ligation and acetic acid induced gastric lesions.

\section{Materials and Methods}

\subsection{Plant Material and Preparation of Extracts}

Plant materials were collected in Dschang, Menoua Division in the West Region of Cameroon in September 2011 and authenticated at the National Herbarium of Cameroon in comparison with the existing Voucher specimen $n^{\circ}$ (BUD 75). The harvested fresh leaves were shade dried and coarsely powdered.

Two hundred grams of the powder was boiled in 1 litre of distilled water for $15 \mathrm{~min}$. The decoction was taken and allowed to cool for $45 \mathrm{~min}$ at room temperature $\left(24 \pm 2^{\circ} \mathrm{C}\right)$, filtered twice and then evaporated to dryness in an oven at $50^{\circ} \mathrm{C}$, to give $38.13 \mathrm{~g}$ of the aqueous extract corresponding to an extraction yield of $19.10 \%$.

For preparation of the methanol extract, $416.00 \mathrm{~g}$ of the powder was macerated in 2 litres of methanol for $72 \mathrm{hrs}$. The filtrate was concentrated to dryness in a rotary evaporator under reduced pressure at a temperature of $65^{\circ} \mathrm{C}$ to give $40.00 \mathrm{~g}$ of a green soluble residue, corresponding to an extraction yield of $9.62 \%$.

\subsection{Animals}

The experiments were carried out on Wistar strain male adult rats, between 12 and 16 weeks old and weighing on average $180 \mathrm{~g}$. The rats were bred in the animal house of the Faculty of Science at the University of Dschang in colony cages and exposed to $12 \mathrm{hrs}$ dark/light cycle. They were fed on normal laboratory rat diet with water given ad libitum. Prior to experimental 
protocol, the rats were acclimatized for $48 \mathrm{hrs}$ to laboratory conditions to minimize any nonspecific stress.

For each experiment, animals were divided into 11 groups of 6 each. Group 1 served as the normal control group and received per os distilled water only. Groups 2 and 3 served as negative control and received distilled water and a mixture of DMSO (5\%)/Tween (3\%), respectively. Groups 4 and 5 which served as positive control received Cimetidine $(12 \mathrm{mg} / \mathrm{kg})$ and Maalox (50 mg/kg), respectively. Finally groups 6-11 received aqueous and methanolic extracts at doses of 125, 250 and $500 \mathrm{mg} / \mathrm{kg}$. All treatments were administered orally at the corresponding volume of $1 \mathrm{ml} / 100 \mathrm{~g}$ body weight and the animals were kept in cages with raised floors of wide mesh to prevent coprophagy.

All procedures described in the present work as concerns the use of experimental animals were in strict respect of the ethics regarding the use, handling and preservation of the Cameroonian flora and fauna as specified by the Ethics Committee of the Cameroon Ministry of Scientific Research and Technology, which has adopted the guidelines established by the European union on animal care and experimentation (CCE Council 86/609).

\subsection{Chemicals}

DMSO, Tween, $\mathrm{HCl} /$ ethanol, acetic acid, $\mathrm{NaOH}$ and $\mathrm{NaCl}$ were obtained from Sigma Chemicals. Maalox ${ }^{\circledR}$ and Cimetidine ${ }^{\circledR}$ were purchased from a pharmacy. All other used chemicals and reagents were of analytical grade.

\subsection{Experimental Procedure}

\subsubsection{Hcl/Ethanol-Induced Ulcers}

An evaluation of the pharmacological activity of aqueous and methanolic extracts of leaves of Rumex bequaertii on induced gastric ulceration was based on the method of Hara and Okabe (1985). One hour after drug treatment, $1 \mathrm{ml} / 150 \mathrm{~g}$ body weight of the necrotizing solution (150 $\mathrm{mM} \mathrm{HCl}$ in $60 \%$ ethanol) was given per os to each rat. The animals were sacrificed 1 hour later using an overdose of ether, and then the stomach removed and observed for ulcer in the glandular region. The surface area of each lesion was measured and scored as described by Tan et al. (1996). The ulcer index for each rat was taken as the mean ulcer score (0: no ulcer; 1: US $\leq 0.5 \mathrm{~mm}^{2} ; 2: 0.5 \mathrm{~mm}^{2}<\mathrm{US} \leq 2.5 \mathrm{~mm}^{2} ; 3: 2.5 \mathrm{~mm}^{2}<\mathrm{US} \leq 5 \mathrm{~mm}^{2} ; 4: 5 \mathrm{~mm}^{2}<\mathrm{US} \leq 10 \mathrm{~mm}^{2} ; 5:$ $10 \mathrm{~mm}^{2}<\mathrm{US} \leq 15 \mathrm{~mm}^{2} ; 6: 15 \mathrm{~mm}^{2}<\mathrm{US} \leq 20 \mathrm{~mm}^{2} ; 7: 20 \mathrm{~mm}^{2}<\mathrm{US} \leq 25 \mathrm{~mm}^{2} ; 8: 25 \mathrm{~mm}^{2}<\mathrm{US} \leq$ $30 \mathrm{~mm}^{2} ; 9: 30 \mathrm{~mm}^{2}<\mathrm{US} \leq 35 \mathrm{~mm}^{2} ; 10: \mathrm{US}>35 \mathrm{~mm}^{2}$ ). The percentage ulcerated surface was calculated as the total area covered by all lesions expressed as a proportion of the total corpus mucosal surface area. The percentage of inhibition (I \%) was calculated as described by Nguelefack et al. (2005) and Ateufack et al. (2006) using the following formula:

$$
\% I=\frac{\left(U S_{c}-U S_{t}\right)}{U S_{c}} \times 100
$$

Where $U S_{c}=$ Ulcer surface area of control and $U S_{t}=$ Ulcer surface area of treated animals. 
The mucus covering the gastric wall of each rat was collected and weighed.

\subsubsection{Pyloric-Ligated Ulcer Technique}

This method was used to investigate the neutralizing properties and antisecretory effect of the extracts of $R$. bequaertii. The rats were given ( $1 \mathrm{ml} / 100 \mathrm{~g}$ body weight) the aqueous and methanolic extracts $(125,250$ and $500 \mathrm{mg} / \mathrm{kg})$, cimetidine $(12 \mathrm{mg} / \mathrm{kg})$, Maalox $(50 \mathrm{mg} / \mathrm{kg})$, distilled water or a mixture of DMSO /Tween.

One hour before the treatment, the pylorus of each rat was tied under light ether anesthesia and the abdominal incision was closed. Six hours after ligation, the animals were sacrificed using sodium thiopental solution and the stomach removed. A small nick was made at the junction of the pylorus ligation and greater curvature. Gastric contents were collected in centrifuge tubes and centrifuged at $2000 \mathrm{rpm}$ for $20 \mathrm{~min}$. The volume of supernatant fluid was measured and used for $\mathrm{pH}$ analysis. The stomach was opened along the greater curvature and ulcer produced was graded according to a modification of the method described by Shay et al. (1945): 0, absence of ulcer; 1 , vessel dilatation and pointed ulcers; 2.5 , small ulcer < $4 \mathrm{~mm}$ long; 3.5, 4 $\mathrm{mm}$ long $\leq$ ulcer $\geq 5 \mathrm{~mm}$ long; 5 , large ulcer $>5 \mathrm{~mm}$ long. The ulcer index, the percentage ulcerated and the percentage of inhibition were estimated as described above.

To measure the gastric acidity, $1 \mathrm{ml}$ of the total centrifuged gastric contents from each pylorus-ligated rat was analyzed for hydrogen ion concentration by titrating against a $0.01 \mathrm{~N}$ solution of $\mathrm{NaOH}$ using a pH meter (Consort C-533). The experiment was done in triplicate.

\subsubsection{Acetic Acid-Induced Chronic Ulcer}

The experiment was performed according to the method described by Takagi et al. (1969) with some modifications. All groups consisted of rats which were fasted for 24 hours. Under anesthesia resulting from a Diazepam/Ketamine (0.3/0.1 v/v) mixture, a laparotomy was performed on all animals except the normal control animals through a midline epigastric incision. After exposing the stomach, $0.05 \mathrm{ml}$ of a $30 \%$ (v/v) acetic acid solution was injected into the subserosal layer in the glandular part of the anterior wall. The stomach was bathed with $\mathrm{NaCl}(0.9 \%)$ solution in order to avoid adherence to the external surface of the ulcerated region and the abdomen was then stitched up. All animals received penicillin $(0.02 \mathrm{ml})$ intramuscular injection for three days to protect against infections. One day after administration of acid, daily treatment began and animals were treated orally once a day for 14 consecutive days. On the day 15, all groups were sacrificed. The blood was collected and the stomachs were removed. The blood was used to determine the nitric oxide level and the stomachs for evaluating the ulcerated area, mucus weight, nitric oxide level and histological assessment.

\subsection{Histological Assessment}

One part of the stomach was preserved in $10 \%$ formalin solution followed by tissue dehydration with alcohol and xylene. Each sample was then embedded in paraffin wax, sectioned at $5 \mu \mathrm{m}$ in slides prior to staining. Haematoxylin and eosin stain was used. The slides were examined under light microscope with 40x lenses, and recorded. 


\subsection{Measurement of Mucus Production}

Gastric mucus production was measured in the rats subjected to $\mathrm{HCl} / \mathrm{ethanol}$, pylorus ligation and acetic acid according to the method described by Tan and Nyasse, (2000). Gastric mucosa of each rat was gently scraped using a glass slide, and the mucus obtained was carefully weighed using a sensitive digital electronic balance. This operation was performed by the same experimenter each time.

\subsection{Blood Collection}

The heparinized blood samples of the rats were obtained from the cardiac puncture. Immediately after puncture, the blood was removed and submitted to centrifugation (2000 rpm) for $20 \mathrm{~min}$. After the centrifugation, the plasma obtained was preserved at $-18^{\circ} \mathrm{C}$ until used for nitric oxide $(\mathrm{NO})$ dosage.

\subsection{Preparation of Gastric Supernatant}

After induction of gastric ulcer by acetic acid, the glandular stomach was cut into two parts. One part was weighed, crushed and homogenized in $0.4 \mathrm{M}$ carbonate buffer $(\mathrm{pH} 10.2)$. The homogenate was centrifuged at $2000 \mathrm{rpm}$ for $15 \mathrm{~min}$ to remove cell debris and nuclei and the resultant supernatant was preserved at $-18^{\circ} \mathrm{C}$ until used for estimation of NO.

\subsection{Nitric Oxide Dosage}

After acetic acid induction, the heparinized blood and the homogenized stomach of the rats were used to measure the nitric oxide level in accordance with the method described by Sreejayan and Rao, (1997) and repeated by Umamaheswari et al. (2006) with some modifications. NO content was quantified by measuring nitrite/nitrate concentration using Griess assay and sodium nitrite was used as standard. In brief, gastric homogenates were deproteinated with absolute ethanol for $48 \mathrm{hrs}$ at $4^{\circ} \mathrm{C}$, then centrifuged at $3.000 \mathrm{rpm}$ for 15 minutes at $4^{\circ} \mathrm{C}$. To an aliquot of the supernatant, vanadium trichloride $0.8 \%(\mathrm{~W} / \mathrm{V})$ in $1 \mathrm{M} \mathrm{HCl}$ was added for the reduction of nitrate to nitrite, followed by the rapid addition of Griess reagent (sigma) and the absorbance at $540 \mathrm{~nm}$ was measured.

\subsection{Statistical Analysis}

Statistical analysis was performed using one-way analysis of variance (ANOVA) followed by Turkey's test for post-hoc analysis. Significant difference between treatments was accepted at $\mathrm{p}<0.05$. Data analysis was achieved using the software program GraphPad InStat and values were expressed as mean \pm standard error of the mean.

\section{Results}

\subsection{PH of Extracts and Reference Solutions}

The aqueous and methanolic extracts from leaves of Rumex bequaertii at the concentrations 125,250 and $500 \mathrm{mg} / \mathrm{kg}$ showed respective $\mathrm{pH}$ values of 6.09, 6.07, 6.00 and 4.76, 4.76 and 4.72. The Cimetidine and Maalox at respective concentrations of $12 \mathrm{mg} / \mathrm{kg}$ and $50 \mathrm{mg} / \mathrm{kg}$ showed respective $\mathrm{pH}$ values of 8.97 and 8.50 (Table 1). 
Table 1. PH of extracts and reference solutions

\begin{tabular}{|c|l|l|}
\hline Solutions & Dose $(\mathrm{mg} / \mathrm{kg})$ & $\mathrm{pH}$ \\
\hline \multirow{4}{*}{ A.E } & 125 & 6.09 \\
\cline { 2 - 3 } & 250 & 6.07 \\
\cline { 2 - 3 } & 500 & 6.00 \\
\hline \multirow{3}{*}{ M.E } & 125 & 4.76 \\
\cline { 2 - 3 } & 250 & 4.76 \\
\cline { 2 - 3 } & 500 & 4.72 \\
\hline Cimetidine & 12 & 8.97 \\
\hline Maalox & 50 & 8.50 \\
\hline
\end{tabular}

A.E= Aqueous extract; M.E= Methanol extract

\subsection{Hcl/Ethanol-Induced Ulcers}

Oral administration of necrotic $\mathrm{HCl} /$ ethanol solution produced a characteristic lesion in the glandular portion of the stomach of rats one hour later that appeared as elongated, thick, black and dark red strips with a mean ulcer area of $137.30 \pm 7.30$ and $71.25 \pm 4.96 \mathrm{~mm}^{2}$ in the negative control groups that respectively received distilled water and a mixture of DMSO/Tween (Table 2).

Preventive treatment of ulceration of the gastric mucosa against the necrotic effects of $\mathrm{HCl} /$ ethanol with aqueous extract of the leaves of Rumex bequaertii produced a dose-dependent inhibition of gastric ulceration that comprised of $51.84 \%$ at a dose of 125 $\mathrm{mg} / \mathrm{kg}$ and $98.86 \%$ at a dose of $500 \mathrm{mg} / \mathrm{kg}$, with respective ulcer surface areas of $66.12 \pm 9.51$ and $1.56 \pm 1.01 \mathrm{~mm}^{2}$. The mass of mucus of the control animals that received distilled water $(103.70 \pm 12.49 \mathrm{mg})$ significantly $(\mathrm{p}<0.01)$ increased in rats treated with the respective doses of 125,250 and $500 \mathrm{mg} / \mathrm{kg}$ of the aqueous extract of the plant. The corresponding masses were $133.60 \pm 9.83,129.50 \pm 7.60$ and $161.50 \pm 13.78 \mathrm{mg}$ (table 2$)$. In parallel a significant ( $<0.001)$ dose dependent reduction of percentage ulcerated surface from $9.55 \pm 0.55 \%$ in the control animals treated with distilled water to $4.90 \pm 0.75 ; 1.83 \pm 0.61$ and $0.24 \pm 0.18 \%$ at the respective doses of 125,250 and $500 \mathrm{mg} / \mathrm{kg}$ of the aqueous extract was observed.

The methanolic extract produced a dose-dependent average ulcer index decreasing with a significant reduction $(\mathrm{p}<0.05)$ in rats treated at the dose of $500 \mathrm{mg} / \mathrm{kg}(2.42 \pm 0.16)$ compared to the control group that received DMSO/Tween mixture $(4.80 \pm 0.30)$.

Independently of the dose considered, animals receiving the methanolic extract had significantly $(p<0.001)$ increased mucus production when compared to the control group earlier treated with DMSO/Tween mixture.

The percentage of surface ulceration experienced a significant reduction $(\mathrm{p}<0.001)$ from 4.76 $\pm 0.43 \%$ in the control animals that received DMSO/Tween mixture to $1.61 \pm 0.34$ and $0.75 \pm$ $0.10 \%$ respectively in the groups treated with methanolic extract at doses 250 and $500 \mathrm{mg} / \mathrm{kg}$ (Table 2).

Moreover a significant reduction $(\mathrm{p}<0.001)$ of ulcer surface area was observed in the animals 
receiving 250 and $500 \mathrm{mg} / \mathrm{kg}$ of methanolic extract. The total surface area of $71.25 \pm 4.96 \mathrm{~mm}^{2}$ in rats receiving DMSO/Tween mixture decease to $23.54 \pm 4.53$ and $11.59 \pm 1.88 \mathrm{~mm}^{2}$ respectively in animals treated with the methanol extract at doses of 250 and $500 \mathrm{mg} / \mathrm{kg}$.

Animals treated with Cimetidine at a dose of $12 \mathrm{mg} / \mathrm{kg}$ produced an ulcer surface area of 70.56 $\pm 2.49 \mathrm{~mm}^{2}$ corresponding to $48.61 \%$ inhibition, and Maalox produced a significant $(\mathrm{p}<0,001)$ decrease in ulcer surface area from $137.30 \pm 7.30 \mathrm{~mm}^{2}$ to $54.86 \pm 1.10 \mathrm{~mm}^{2}$ at a dose of 50 $\mathrm{mg} / \mathrm{kg}$, leading to an inhibition percentage of $60.04 \%$ (Table 2).

Table 2. Preventive effects of aqueous and methanolic extracts of Rumex bequaertii leaves on necrotizing $\mathrm{HCl} /$ ethanol-induced gastric lesions in rats

\begin{tabular}{|l|l|l|l|l|l|l|l|}
\hline Treatment & $\mathrm{n}$ & $\begin{array}{l}\text { Dose } \\
(\mathrm{mg} / \mathrm{kg})\end{array}$ & $\begin{array}{l}\text { US area } \\
\left(\mathrm{mm}^{2}\right)\end{array}$ & Ulcer index & $\%$ US & $\% \mathrm{I}$ & $\begin{array}{l}\text { Mucus weight } \\
(\mathrm{mg})\end{array}$ \\
\hline Normal & 6 & $/$ & $/$ & $/$ & $/$ & $/$ & $40.20 \pm 5.89$ \\
\hline $\begin{array}{l}\text { Distilled } \\
\text { water }\end{array}$ & 6 & $/$ & $137.30 \pm 7.30$ & $5.89 \pm 0.61$ & $9.55 \pm 0.55$ & $/$ & $103.70 \pm 12.49$ \\
\hline $\begin{array}{l}\text { DMSO/ } \\
\text { Tween } 80\end{array}$ & 6 & $/$ & $71.25 \pm 4.96$ & $4.80 \pm 0.30$ & $4.76 \pm 0.43$ & $/$ & $91.62 \pm 3.03$ \\
\hline Cimetidine & 6 & 12 & $70.56 \pm 2.49^{* * *}$ & $4.48 \pm 0.39$ & $5.14 \pm 0.30^{* * *}$ & 48.61 & $172.10 \pm 7.83^{* * * *}$ \\
\hline Maalox & 6 & 50 & $54.86 \pm 1.10^{* * *}$ & $4.05 \pm 0.22$ & $4.08 \pm 0.33^{* * *}$ & 60.04 & $80.18 \pm 5.83$ \\
\hline \multirow{2}{*}{$\begin{array}{l}\text { Aqueous } \\
\text { extract }\end{array}$} & 6 & 125 & $66.12 \pm 9.51^{* * *}$ & $4.67 \pm 0.36$ & $4.90 \pm 0.75^{* * *}$ & 51.84 & $133.60 \pm 9.83^{* *}$ \\
\cline { 2 - 8 } & 6 & 250 & $21.44 \pm 7.25^{* * * *}$ & $2.94 \pm 1.06$ & $1.83 \pm 0.61^{* * *}$ & 84.38 & $129.50 \pm 7.60^{* *}$ \\
\cline { 2 - 8 } & 6 & 500 & $1.56 \pm 1.01^{* * *}$ & $0.83 \pm 0.54$ & $0.24 \pm 0.18^{* * *}$ & 98.86 & $161.50 \pm 13.78^{* * * *}$ \\
\hline \multirow{2}{*}{$\begin{array}{l}\text { Methanol } \\
\text { extract }\end{array}$} & 6 & 125 & $59.18 \pm 6.60$ & $4.47 \pm 0.33$ & $3.60 \pm 0.42$ & 56.89 & $181.90 \pm 5.01 \mathrm{c}$ \\
\cline { 2 - 8 } & 6 & 250 & $23.54 \pm 4.53 \mathrm{c}$ & $2.93 \pm 0.16$ & $1.61 \pm 0.34 \mathrm{c}$ & 82.85 & $152.80 \pm 9.89 \mathrm{c}$ \\
\cline { 2 - 8 } & 6 & 500 & $11.59 \pm 1.88 \mathrm{c}$ & $2.42 \pm 0.16 \mathrm{a}$ & $0.75 \pm 0.10 \mathrm{c}$ & 91.59 & $167.10 \pm 9.50 \mathrm{c}$ \\
\hline
\end{tabular}

$\mathrm{n}=$ number of rats per group; $\mathrm{I}=$ inhibition; $\mathrm{US}=$ ulcer surface

${ }^{* *} \mathrm{p}<0.01 ;{ }^{* * *} \mathrm{p}<0.001$ statistically significant relative to control animals treated with distilled water.

${ }^{\mathrm{a}} \mathrm{p}<0.05 ; \quad{ }^{\mathrm{c}} \mathrm{p}<0.001$ statistically significant relative to control animals treated with DMSO/Tween80 mixture.3.3. Pylorus ligation-induced ulcers

The results shown in Table 3 are those obtained when ulceration of the gastric mucosa was provoked by ligation of the pylorus. Pyloric ligation of rats in the control groups produced pointed lesions or raised inflammations.

The results obtained after oral administration of the aqueous and methanolic extracts of the leaves of Rumex bequaertii indicate that such extracts protected the gastric wall against hydrochloric acid and pepsin autodigestion in gastric contents after pylorus ligation.

Pretreatment of rats with the aqueous extract produced a significant $(\mathrm{p}<0,001)$ decrease in ulcer surface area from $49.40 \pm 1.18 \mathrm{~mm}^{2}$ in control rats treated with distilled water to $5.40 \pm 1.19$, $16.20 \pm 0.61$ and $5.47 \pm 0.44 \mathrm{~mm}^{2}$ respectively in rats treated with the aqueous extract of the 
leaves of Rumex bequaertii at doses of 125,250 et $500 \mathrm{mg} / \mathrm{kg}$, leading to inhibition percentage of $89.07,66.21$ and $88.93 \%$, respectively. The mucus weight of the control animals $(58.37 \mathrm{mg})$ significantly $(\mathrm{p}<0.05)$ increased to 91.80 and $91.57 \mathrm{mg}$ respectively in those receiving 125 and $250 \mathrm{mg} / \mathrm{kg}$ of aqueous extract.

The methanolic extract produced 90.43, 94.74 and $63.66 \%$ inhibition respectively at doses of 125,250 and $500 \mathrm{mg} / \mathrm{kg}$ with corresponding ulcer surface areas of $4.73 \pm 1.01,2.60 \pm 1.12$ and $17.95 \pm 2.14 \mathrm{~mm}^{2}$. The mean ulcer index scored decreased significantly $(\mathrm{p}<0.001)$ from $4.39 \mathrm{in}$ control animals receiving DMSO/Tween mixture to 2.50 and 2.12 for rats treated with 125 and $250 \mathrm{mg} / \mathrm{kg}$ of the methanolic extract, respectively. The methanolic extract at doses of 125,250 and $500 \mathrm{mg} / \mathrm{kg}$ produced a significant $(\mathrm{p}<0,001)$ increase of the mucus weight $(95.90,105.70$ and $93.30 \mathrm{mg}$ respectively) compared to negative control group treated with DMSO/Tween mixture $(45.48 \mathrm{mg}$ ). Considering the volume of gastric juice, the $\mathrm{pH}$ of gastric juice and the gastric acidity, no significant $(\mathrm{p}>0.05)$ variation was observed compared to negative control group treated with the mixture DMSO/Tween.

Animals treated with Cimetidine at a dose of $12 \mathrm{mg} / \mathrm{kg}$ produced an ulcer surface area of 22.01 $\pm 2.09 \mathrm{~mm}^{2}$ corresponding to $55.45 \%$ inhibition while Maalox produced a significant $(\mathrm{p}<0,001)$ decrease in ulcer surface area from $49.40 \pm 1.18 \mathrm{~mm}^{2}$ to $26.15 \pm 1.65 \mathrm{~mm}^{2}$ at a dose of 50 $\mathrm{mg} / \mathrm{kg}$, leading to inhibition percentage of $47.06 \%$ compared to control animals receiving distilled water (Table 3).

Table 3. Preventive effects of aqueous and methanolic extracts of Rumex bequaertii leaves on pylorus ligation ulceration

\begin{tabular}{|c|c|c|c|c|c|c|c|c|c|c|}
\hline Treatment & $\mathrm{n}$ & Dose $(\mathrm{mg} / \mathrm{kg})$ & $\mathrm{US}$ area $\left(\mathrm{mm}^{2}\right)$ & Ulcer index & $\%$ US & $\% \mathrm{I}$ & $\begin{array}{l}\text { Gastric } \\
\text { juice (ml) }\end{array}$ & Gastric $\mathrm{pH}$ & $\begin{array}{l}\text { Gastric } \\
\qquad \text { acidity } \\
\qquad(\mathrm{mEq} / \mathrm{l})\end{array}$ & $\begin{array}{c}\text { Mucus weight } \\
(\mathrm{mg})\end{array}$ \\
\hline Normal & 6 & I & I & I & I & I & I & I & I & $50.12 \pm 3.42$ \\
\hline $\begin{array}{l}\text { Distilled } \\
\text { water }\end{array}$ & 6 & I & $49.40 \pm 1.18$ & $4.47 \pm 0.24$ & $5.68 \pm 0.52$ & / & $5.23 \pm 1.51$ & $2.77 \pm 0.27$ & $125.00 \pm 6.78$ & $58.37 \pm 1.98$ \\
\hline $\begin{array}{l}\text { DMSO+ } \\
\text { Tween } 80\end{array}$ & 6 & l & $32.19 \pm 1.36$ & $4.39 \pm 0.15$ & $4.03 \pm 0.25$ & l & $2.21 \pm 0.15$ & $3.21 \pm 0.24$ & $103.30 \pm 9.44$ & $45.48 \pm 4.34$ \\
\hline Cimetidine & 6 & 12 & $22.01 \pm 2.09^{* * *}$ & $3.81 \pm 0.32$ & $2.60 \pm 0.20^{* * *}$ & 55.45 & $4.88 \pm 1.01$ & $2.93 \pm 0.22$ & $120.50 \pm 4.99$ & $79.18 \pm 3.28$ \\
\hline Maalox & 6 & 50 & $26.15 \pm 1.65^{* * *}$ & $3.93 \pm 0.39$ & $2.96 \pm 0.33^{* * *}$ & 47.06 & $6.12 \pm 1.44$ & $3.35 \pm 0.21$ & $105.50 \pm 4.99$ & $67.75 \pm 1.94$ \\
\hline \multirow{3}{*}{$\begin{array}{l}\text { Aqueous } \\
\text { extract }\end{array}$} & 6 & 125 & $5.40 \pm 1.19^{* * * *}$ & $2.92 \pm 0.26^{*}$ & $0.68 \pm 0.15^{* * *}$ & 89.07 & $4.07 \pm 0.42$ & $2.49 \pm 0.16$ & $131.80 \pm 5.54$ & $91.80 \pm 7.03^{*}$ \\
\hline & 6 & 250 & $16.20 \pm 0.61^{* * *}$ & $3.47 \pm 0.19^{* * *}$ & $1.65 \pm 0.22^{* * *}$ & 66.21 & $8.20 \pm 0.73$ & $3.20 \pm 0.26$ & $112.20 \pm 9.53$ & $91.57 \pm 4.27^{*}$ \\
\hline & 6 & 500 & $5.47 \pm 0.44^{* * *}$ & $2.72 \pm 0.15^{* *}$ & $0.71 \pm 0.07^{* * *}$ & 88.93 & $3.74 \pm 1.12$ & $2.74 \pm 0.21$ & $127.00 \pm 3.77$ & $80.76 \pm 3.33$ \\
\hline \multirow{3}{*}{$\begin{array}{l}\text { Methanol } \\
\text { extract }\end{array}$} & 6 & 125 & $4.73 \pm 1.01^{\mathrm{c}}$ & $2.50 \pm 0.00^{c}$ & $0.60 \pm 0.13^{\mathrm{c}}$ & 90.43 & $3.61 \pm 0.65$ & $2.65 \pm 0.15$ & $127.00 \pm 5.22$ & $95.90 \pm 15.72^{\mathrm{c}}$ \\
\hline & 6 & 250 & $2.60 \pm 1.12^{\mathrm{c}}$ & $2.12 \pm 0.52^{\mathrm{c}}$ & $0.25 \pm 0.09^{\mathrm{c}}$ & 94.74 & $2.60 \pm 0.30$ & $3.52 \pm 0.55$ & $111.20 \pm 9.19$ & $105.70 \pm 10.55^{\mathrm{c}}$ \\
\hline & 6 & 500 & $17.95 \pm 2.14^{\mathrm{c}}$ & $3.70 \pm 0.30$ & $2.07 \pm 0.34^{c}$ & 63.66 & $5.12 \pm 1.17$ & $3.10 \pm 0.28$ & $110.30 \pm 9.90$ & $93.30 \pm 3.64^{\mathrm{c}}$ \\
\hline
\end{tabular}

$\mathrm{n}=$ number of rats per group; $\mathrm{I}=$ inhibition; US = ulcer surface

${ }^{*} \mathrm{p}<0.05 ;{ }^{* *} \mathrm{p}<0.01 ;{ }^{* * *} \mathrm{p}<0.001$ statistically significant relative to control animals treated with distilled water. 
cp $<0.001$ statistically significant relative to control animals treated with DMSO/Tween 80 mixture.

\subsection{Acetic Acid-Induced Gastric Ulcers}

Representative images of the acetic acid-induced ulcer model showed very clear ulcer margins with deep defects of the mucous layer. Progressive healing of ulcers with time was defined very well in both treated groups. In this acetic acid-induced ulcer models, the initial ulcer areas for control animals receiving distilled water was $77.11 \pm 9.76 \mathrm{~mm}^{2}$. The oral administration of the aqueous extract of the leaves of Rumex bequaertii at the doses of 125,250 and $500 \mathrm{mg} / \mathrm{kg}$ for 14 consecutive days accelerated the healing of gastric ulcers with a significantly $(\mathrm{p}<0.05)$ decreased in ulcer surface area from $77.11 \pm 9.76 \mathrm{~mm}^{2}$ to $41.75 \pm 9.27,43.78 \pm 9.40$ and $7.62 \pm$ $1.91 \mathrm{~mm}^{2}$ respectively, leading to inhibition percentage of $45.86,43.22$ and $90.11 \%$ respectively.

Postoperative treatment with methanolic extract $(125$ and $500 \mathrm{mg} / \mathrm{kg})$ significantly $(\mathrm{p}<0.01)$ reduced the mean area of chronic ulcer $\left(8.52 \pm 1.33\right.$ and $7.51 \pm 1.54 \mathrm{~mm}^{2}$ versus $27.70 \pm 8.59$ $\mathrm{mm}^{2}$ in the control animals receiving DMSO/Tween mixture), corresponding to an inhibition percentage of 69.24 and $72.89 \%$ respectively.

Oral administration of Cimetidine at a dose of $12 \mathrm{mg} / \mathrm{Kg}$ produced no significant variation $(\mathrm{p}>0.05)$ on the ulcer surface $\left(104.80 \pm 6.07 \mathrm{~mm}^{2}\right)$ and the percentage ulcerated surface $(11.08$ $\pm 1.21 \%)$ compared to negative control rats treated with distilled water $\left(77.11 \pm 9.76 \mathrm{~mm}^{2}\right.$ and $8.65 \pm 3.13 \%)$ respectively. In contrast, the mucus weight significantly $(p<0.001)$ increased from $54.12 \mathrm{mg}$ in animals given distilled water to $119.70 \mathrm{mg}$ in rats that received Cimetidine. Rats treated with Maalox $(50 \mathrm{mg} / \mathrm{kg})$ showed a significant $(\mathrm{p}<0.001)$ reduction of ulcer surface area $\left(25.30 \pm 3.71 \mathrm{~mm}^{2}\right)$ and the percentage ulcerated surface $(2.62 \pm 0.54 \%)$ compared to the negative control rats that were given distilled water $\left(77.11 \pm 9.76 \mathrm{~mm}^{2}\right.$ and $\left.8.65 \pm 3.13 \%\right)$. In contrast, no significant difference ( $p>0.05$ ) is observed in terms of the mass of mucus produced between the group of rats that received Maalox $(46.53 \mathrm{mg})$ and negative control groups treated with distilled water $(54.12 \mathrm{mg})$.

Table 4. Effects of aqueous and methanol extracts of Rumex bequaertii leaves on gastric ulcer induced by acetic acid

\begin{tabular}{|l|c|l|l|l|l|}
\hline Traitment & $\mathrm{n}$ & Dose $(\mathrm{mg} / \mathrm{kg})$ & $\mathrm{US}\left(\mathrm{mm}^{2}\right)$ & $\%$ US \%I & Mucus weigth $(\mathrm{mg})$ \\
\hline Normal & 6 & \multicolumn{1}{|c|}{$/$} & \multicolumn{1}{c|}{$/$} & \multicolumn{1}{c|}{$/$} & $53.55 \pm 5.21$ \\
\hline Distilled water & 6 & $/$ & $77.11 \pm 9.76$ & $8.65 \pm 3.13$ & $54.12 \pm 5.13$ \\
\hline DMSO+Tween & 6 & $/$ & $27.7 \pm 8.59$ & $3.51 \pm 2.47$ & $30.77 \pm 1.54$ \\
\hline Cimetidine & 6 & 12 & $104.8 \pm 6.07$ & $11.08 \pm 1.21$ & $119.70 \pm 4.61^{* * *}$ \\
\hline Maalox & 6 & 50 & $25.30 \pm 3.71^{* * *}$ & $2.62 \pm 0.54^{* * *} 67.19$ & $46.53 \pm 2.76$ \\
\hline $\begin{array}{l}\text { Aqueous } \\
\text { extract }\end{array}$ & 6 & 125 & $41.75 \pm 9.27^{* *}$ & $4.11 \pm 0.70^{* * *} 45.86$ & $104.90 \pm 6.44^{* *}$ \\
\cline { 2 - 6 } & 6 & 250 & $43.78 \pm 9.40^{* *}$ & $3.87 \pm 0.73^{* * *} 43.22$ & $133.20 \pm 17.38^{* * *}$ \\
\cline { 2 - 6 } & 6 & 500 & $7.62 \pm 1.91^{* * * *}$ & $0.80 \pm 0.22^{* * *} 90.11$ & $106.60 \pm 17.67^{* *}$ \\
\hline
\end{tabular}




\begin{tabular}{|l|l|l|l|l|l|}
\hline \multirow{2}{*}{$\begin{array}{l}\text { Methanol } \\
\text { extract }\end{array}$} & 6 & 125 & $8.52 \pm 1.33^{* *}$ & $1.00 \pm 0.3069 .24$ & $115.70 \pm 4.92^{\mathrm{c}}$ \\
\cline { 2 - 6 } & 6 & 250 & $19.31 \pm 3.24$ & $1.95 \pm 0.4130 .29$ & $123.20 \pm 11.25^{\mathrm{c}}$ \\
\cline { 2 - 6 } & 6 & 500 & $7.51 \pm 1.54^{* *}$ & $0.87 \pm 0.2472 .89$ & $108.20 \pm 4.60^{\mathrm{c}}$ \\
\hline
\end{tabular}

$\mathrm{n}=$ number of rats per group; US = ulcerated surface

${ }^{*} \mathrm{p}<0.05 ;{ }^{* *} \mathrm{p}<0.01 ;{ }^{* * *} \mathrm{p}<0.001$ statistically significant relative to control animals treated with distilled water.

${ }^{c} \mathrm{p}<0.001$ statistically significant relative to control animals treated with DMSO/Tween mixture.

\subsection{Nitric Oxide Secretion}

The effects of Rumex bequaertii production on nitric oxide is represented in Table 5. In the plasma fluid and gastric supernatant, no significant difference $(\mathrm{p}>0.05)$ was observed irrespective of extract used and the dose administered compared to the two negative control groups. However, the concentration of nitric oxide in the gastric supernatant of rats receiving Cimetidine, significantly $(\mathrm{p}<0.001)$ increased from $0.57 \pm 0.07 \mu \mathrm{mol} / \mathrm{g}$ to $1.18 \pm 0.11 \mu \mathrm{mol} / \mathrm{g}$ compared to rats of the negative control group treated with distilled water. Furthermore, no significant $(\mathrm{p}>0.05)$ difference was observed between the animals treated with Maalox and those treated with distilled water.

Table 5. Effects of aqueous and methanolic extracts of Rumex bequaertii leaves on the nitric oxide production

\begin{tabular}{|l|l|l|l|l|}
\hline Treatment & $\mathrm{n}$ & Dose $(\mathrm{mg} / \mathrm{kg})$ & $\begin{array}{l}\text { Concentration of Nitric } \\
\text { oxide in plasma fluid }(\mu \mathrm{M})\end{array}$ & $\begin{array}{l}\text { Concentration of Nitric oxide in } \\
\text { gastric supernatant }(\mu \mathrm{mol} / \mathrm{g})\end{array}$ \\
\hline Normal & 6 & $/$ & $31.25 \pm 11.81$ & $0.40 \pm 0.10$ \\
\hline Distilled water & 6 & $/$ & $17.53 \pm 3.75$ & $0.57 \pm 0.07$ \\
\hline DMSO/Tween & 6 & $/$ & $41.67 \pm 11.15$ & $0.36 \pm 0.09$ \\
\hline Cimetidine & 6 & 12 & $64.32 \pm 12.88$ & $1.18 \pm 0.11^{* * *}$ \\
\hline Maalox & 6 & 50 & $29.17 \pm 5.35$ & $0.48 \pm 0.06$ \\
\hline \multirow{2}{*}{$\begin{array}{l}\text { Aqueous } \\
\text { extract }\end{array}$} & 6 & 125 & $42.19 \pm 8.61$ & $0.38 \pm 0.15$ \\
\cline { 2 - 5 } & 6 & 250 & $29.86 \pm 13.23$ & $0.41 \pm 0.01$ \\
\cline { 2 - 5 } & 6 & 500 & $20.40 \pm 3.17$ & $0.67 \pm 0.04$ \\
\hline \multirow{2}{*}{$\begin{array}{l}\text { Methanol } \\
\text { extract }\end{array}$} & 6 & 125 & $63.19 \pm 17.30$ & $0.43 \pm 0.03$ \\
\cline { 2 - 5 } & 6 & 250 & $23.00 \pm 1.77$ & $0.55 \pm 0.07$ \\
\cline { 2 - 5 } & 6 & 500 & $17.62 \pm 2.27$ & $0.22 \pm 0.07$ \\
\hline
\end{tabular}

$\mathrm{n}=$ number of rats per group.

*** $\mathrm{p}<0.001$ statistically significant relative to control animals treated with distilled water.

\subsection{Histological Examination of Gastric Ulcers}

The histopathology of tissues was performed and results are shown in figure 1 . These results 


\section{Macrothink}

explain the mechanism behind healing of an ulcer and tissue structure when treated with drugs. Figure 1A represents a section taken from the stomach of a rat treated with distilled water and shows the normal histological structure of mucosal layer. Figures 1 (B) and (C) represent the stomach sections of negatively controlled rats subjected to induction of gastric ulcer by subserosal injected acetic acid solution and respectively treated with distilled water and DMSO/Tween mixture. Figure 1B presents a gastric wall with an ulcer crater and cellular necrosis affecting the mucosal layer while Figure 1C shows ulceration with cellular deterioration of the mucus layer. Figures 1 (D) and (E) represent sections taken from stomach of positive control rats that received cimetidine $(12 \mathrm{mg} / \mathrm{kg})$ and Maalox $(50 \mathrm{mg} / \mathrm{kg})$ solution respectively and they all presented normal mucosal layer with edema of mucosa and sub mucosa layer. Figures $1(\mathrm{~F}),(\mathrm{G})$ and $(\mathrm{H})$ present sections taken from the stomach of rats treated with 125,250 and $500 \mathrm{mg} / \mathrm{kg}$ doses of the aqueous extract, respectively. Figure 1F shows several inflammatory cells on the mucosal layer while Figure $1 \mathrm{G}$ presents a normal mucosal layer whereas Figure 1H depicts cellular erosion of the mucosal layer. Figures 1 (I), (J) and (K) present sections taken from the stomach of test rats treated respectively with doses of 125,250 and $500 \mathrm{mg} / \mathrm{kg}$ of the methanolic extract. Figure 1I shows the necrotic cells with ulceration of the mucosal layer next to Figure $1 \mathrm{~J}$ which presents a normal mucosal layer and Figure $1 \mathrm{~K}$ shows a necrotic area of the mucosal layer. 


\section{MInstitute ${ }_{\text {Mnk }}^{\text {Macrothink }}$}
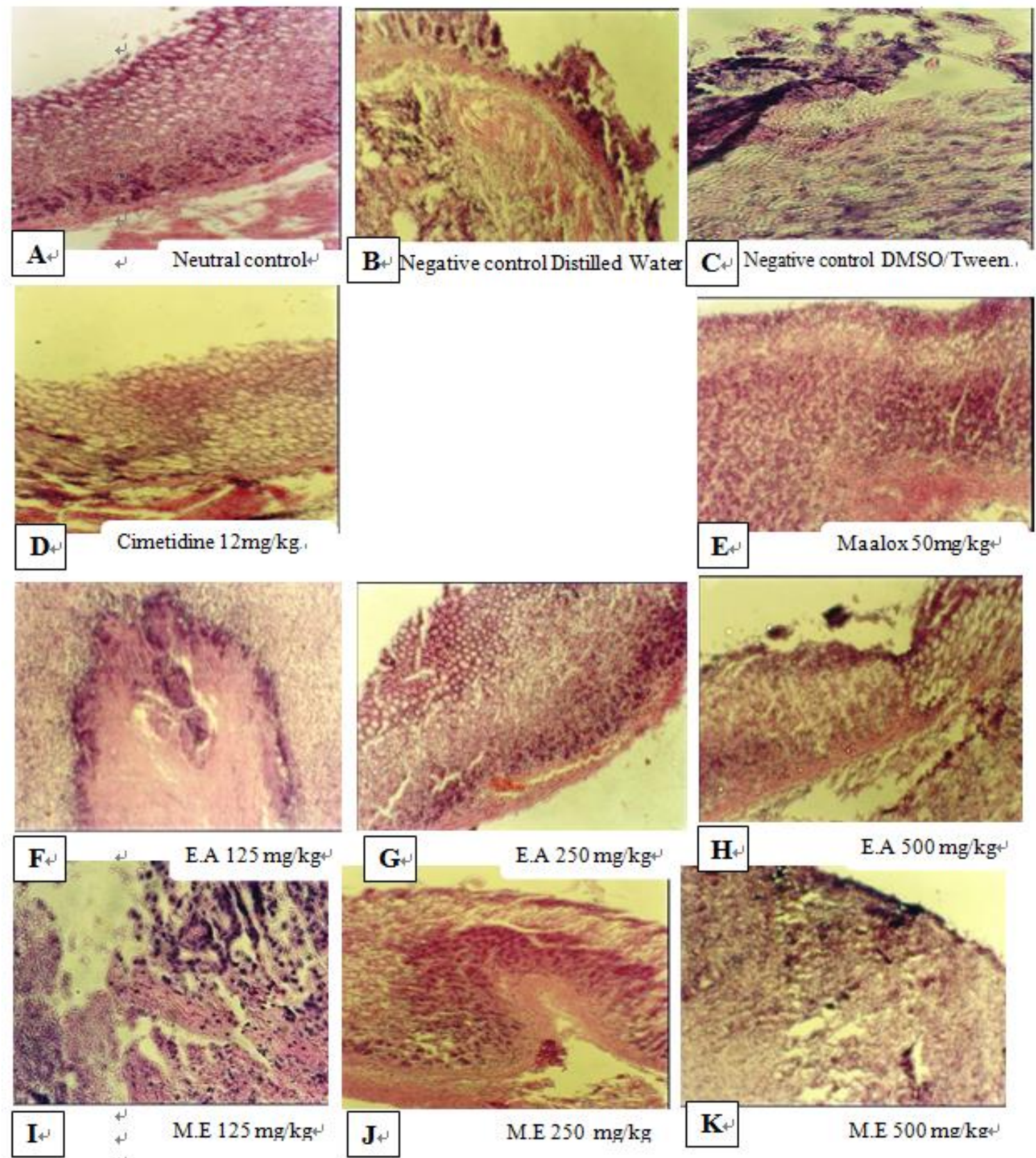

Figure 1. Histopathological studies of antiulcer activity in Acetic acid induced models

\section{Discussion}

The etiology of gastric ulcer is unknown and remains a health problem in the world. It is generally accepted that the ulcer results from an imbalance between aggressive factors and maintenance of the integrity of the gastric mucosa through the mechanism of endogenous defense (Sergio et al., 2007). To maintain this balance, ulcer treatment is based either on the use of antiacid, antispamogenic inhibitors of proton pump antagonists, histamine $\mathrm{H}_{2}$ receptor-type, prostaglandins, cytoprotective, gastric antisecretory and antibiotics to inhibit or reduce gastric acid secretion, or to increase defence mechanisms of gastric mucosa by increasing the production of mucus and bicarbonate, or by stabilizing the surface epithelial cells and 
eradicating bacteria infected with Helicobacter pylori (Ateufack et al., 2006; Nguelefack et al., 2008; Raju et al., 2009). Unfortunately, some of these therapeutic substances have undesirable side effects such as gynecomasia, diarrhea, nephrotoxicity, hepatotoxicity, thrombocytopenia and anaphylaxis (Dharmani et al., 2005; Muralidharan and Srikanth, 2009). For this reason, the search for new drugs is necessary and medicinal plants are among the attractive sources of new drugs that have shown promising results in the treatment of diseases including gastric ulcer (Dharmani and Palit, 2006; Niranjan et al., 2011)

The present study was undertaken to assess the antiulcerogenic and antiulcer properties of aqueous and methanolic extracts of leaves of Rumex bequaertii on adult male rats using three experimental models of inducing gastric ulcer which among others, are induction by $\mathrm{HCl} / \mathrm{ethanol}$, induction by pylorus ligation and induction with acetic acid.

The results of this work showed that aqueous and methanolic extracts at doses of 125, 250 and $500 \mathrm{mg} / \mathrm{kg}$ significantly reduced the effect of ulcerations induced by the three models.

The acute ulcer induction technique $\mathrm{HCl} /$ ethanol mixture was used to study the cytoprotective activity of plant extracts, which materializes cytoprotection by a reduction or absence of lesions (Tan et al., 2000). This model was used because it is more or less similar to that observed in acid hypersecretion cases in human species mechanism. Ethanol in this mixture is considered an excellent gastric ulcer inducing agent. The ethanol diffuses readily through the gastric mucosa by stimulating the release of free radicals which in turn intensifies the lipid peroxidation survives severe cell damage, cell membrane and hydrogen ions backscatter. Thus, exfoliation occurs with loss of epithelial cells which provide the protective activity of the mucosal barrier and alteration of membrane permeability (Lewis and Hanson, 1990; Sikiric et al., 1997 city by Marivane et al., 2011). The use of $\mathrm{HCl}$ in this model is needed to accelerate the ulcerogenesis process, intensify injuries and reduce the mucosal protection against chemical agents. The results obtained in this model show that pre-treatment of rats with aqueous and methanolic extracts of $R$. bequaertii leaves had significant cytoprotective effects. Cytoprotection of the gastric mucosa against necrotizing substances involves several mechanisms such as the potentiating of the mucosal defence by increasing the production of mucus and/or bicarbonate, the reduction of gastric acid secretion or simply neutralizing excess acid (Antonio et al., 2004; Nguelefack et al., 2008) and production of antioxidant (or scavenging reactive oxygen species).

With the exception of rats treated with Maalox $(50 \mathrm{mg} / \mathrm{kg})$, the mass of mucus significantly increased in all other groups of treated rats compared to negative control groups which had received distilled water and DMSO/Tween mixture. It could be that the cytoprotectory effect of aqueous and methanolic extracts may be as a result of the fact that these extracts promote gastric secretion of mucus which covers the gastric wall and then protects it against the attack of $\mathrm{HCl} /$ ethanol. The induction of gastric ulcers with necrotic $\mathrm{HCl} /$ ethanol even though a rapid and indicated technique (Tan et al., 2000) does not allow to determine with certainty the mechanism of action of the aqueous and methanolic extracts of Rumex bequaertii leaves.

To verify the anti-secretory and antiacid activities of aqueous and methanolic extracts of Rumex bequaertii leaves, an induction test in pylorus ligation was performed. Ulcers induced 
by pylorus ligation are the result of two pathophysiological mechanisms: autodigestion of the gastric mucosa by surplus gastric acid and pepsin in the gastric lumen and the reverse interference of gastric blood flow which is the resultant of cells out of the mucosal barrier (Shiramane et al., 2011). The results of this study showed that aqueous and methanolic extracts of Rumex bequaertii leaves significantly reduced the area of ulceration at all doses administered. In contrast, the volume of gastric juice, $\mathrm{pH}$ and gastric acidity, had no significant variation regardless of the dose and extract used. The absence of significant change in the volume, $\mathrm{pH}$ and gastric acidity makes us think that the antiacid and anti-secretory did not press the key mechanisms of action of the plant extracts which is confirmed by the acidic nature of the extracts. However, the mass of mucus increased significantly in all groups that received the aqueous and methanolic extracts which confirms once again that the extracts acted by stimulating the production of mucus. These results are consistent with those obtained by Nguelefack et al. (2008) which showed that the aqueous and methanolic extracts of Solanum torvum leaves could inhibit the formation of lesions induced by $\mathrm{HCl} / \mathrm{ethanol}$ and pylorus ligation by increasing the resistance of mucosal barrier through mucus production.

The induction of ulcer by acetic acid model was selected because this method produces lesions in rats similar to human chronic ulcers. Characteristic of chronic ulcer is that the damage caused by acetic acid does not only reach the mucous membrane and submucosa but also the muscular. In this model, injuries created by acetic acid are limited, and are presented as a crater on the glandular portion of the stomach. The results obtained in this study show that there is a significant reduction in ulcer area and percentages of surface ulceration in rats. Likewise, mucus masses grew significantly in all rats that received the aqueous and methanolic extracts of Rumex bequaertii leaves compared to rats treated with distilled water and DMSO/Tween mixture. These results suggest that aqueous and methanolic extracts of Rumex bequaertii leaves possess healing properties at different doses. This was proven through histological sections of the stomach of rats which received aqueous and methanolic extracts. Accelerated cell regeneration was observed in different treated groups with a complete regeneration of cells of the stomach in animals receiving $250 \mathrm{mg} / \mathrm{kg}$ of aqueous and methanolic extracts compared with two negative control groups where a crater affecting the mucosa and submucosa, and deterioration in the submucosa was observed. Curative and healing properties of aqueous and methanolic extracts of Rumex bequaertii leaves could be attributed to its action on the increased production of mucus, which is an important factor in the process of ulcer healing, because the mucus protects layers of cells against the newly formed acid and pepsin aggression (Cristina et al., 2008).

The Maalox dose of $50 \mathrm{mg} / \mathrm{kg}$ significantly reduced the ulcer surface and the area percentage of ulceration. No change in mass of the mucus was observed in animals treated with Maalox. Maalox $(50 \mathrm{mg} / \mathrm{kg})$ as the aqueous and methanolic extracts $(250 \mathrm{mg} / \mathrm{kg})$ after two weeks of treatment showed a full recovery of the structural architecture of the glandular portion of the stomach. It is known that Maalox which is a combination of aluminum hydroxide and magnesium hydroxide belongs to the class of antacid and gastrointestinal dressing. Through its action, it is able to neutralize the $\mathrm{H}^{+}$ions which protect the gastric mucosa against any form of attack. 


\section{Macrothink}

The results of the histological section showing complete restructuring of the different layers of the gastric mucosa with the two extracts $(250 \mathrm{mg} / \mathrm{kg})$ and Maalox $(50 \mathrm{mg} / \mathrm{kg})$ after two weeks of treatment positively confirms that the aqueous and methanolic extracts of Rumex bequaertii leaves possess curative and healing properties.

Nitric oxide (NO) is a mediator substance long considered in gastrointestinal inflammatory diseases and plays an important role in maintaining the integrity of the mucosa for the synthesis of mucus and bicarbonate (Dominique Lamarque, 1999; Gyires, 2005; Ebtehal et al., 2010). The effect of aqueous and methanolic extracts on the secretion of NO was evaluated in order to better appreciate the mechanisms of tissue healing by the plant extracts. The determination of nitric oxide (NO) after 14 days of treatment showed no significant variation both in plasma fluid and gastric supernatant compared to the two negative controls receiving distilled water and DMSO/Tween. It is known that $\mathrm{NO}$ promotes ulcer healing by stimulating the formation of growth factors, regeneration of epithelial cells, angiogenesis, mucus secretion and opposing the persistence of infiltration of the mucosa by polymorphs. The NO values obtained both in the plasma fluid and gastric supernatant councils the hypothesis that the healing process of the aqueous and methanolic extracts of Rumex bequaertii leaves against chronic ulcer induced by acetic acid would not be the NO pathway.

\section{Conclusion}

Based on the results of the present work we can conclude that the aqueous and methanolic extracts of Rumex bequaertii leaves are endowed with antiulcerogenic and antiulcer properties. Increased mucus production is the major mechanism of action of the plant's leaves extracts in antiulcerogenic process, anti-ulcer and healing of the stomach. However, these extracts have no effect on the production of NO. Our study therefore supports the traditional use of this plant against ulcers.

\section{Acknowledgments}

We gratefully acknowledge Dr. Martin LEKEUFACK who was involved in the drafting and critically revision of this manuscript and the University of Dschang, through the Laboratory of Animal Physiology and Phytopharmacology that provided general support for this work

\section{References}

Aggarwal, P. K., Kumar, L., Garg, S. K., \& Mathur, V.S. (1986). Effect of Rumex nepalensis extracts on histamine, acetylcholine, carbachol, bradykinin, and PGs evoked skin reactions in rabbits. Annals of Allergy, 56(2), 177-182.

Antonio, J. M., Gracioso, J. S., Toma, W., Lopez, L. C., Oliveira, F., Souza, B. A. R. M. (2004). Antiulcerogenic activity of ethanol extract of Solanum variabile (false "jurubeta"). Journal of Ethnoprarmacology, 93, 83-88. http://dx.doi.org/10.1016/j.jep.2004.03.031

Ateufack, G., Nguelefack, T. B., Wabo, H. K., Watcho, P., Tane, P., Kamanyi, A. (2006). Antiulcer effects of the aqueous and organic extracts of the stem bark of Anthocleista vogelii in rats. Pharmaceutical Biology, 44, 1-6. http://dx.doi.org/10.1080/13880200600685915 
Bernard Boullard. (2001). Plantes médicinales du monde. Croyances et réalités. Estem. Paris. France. P. 636.

Borrelli, F., Izzo, A. A., (2000). The plant kingdom as a source of anti-ulcer remedies. Phytotherapy Research, 14, 581-591. http://dx.doi.org/10.1002/1099-1573(200012)14:8<581::AID-PTR776>3.0.CO;2-S

Chopra, R. N., Nayar, S. L., Chopra, I. C. (1986). Glossary of Indian Medicinal Plants (the Supplement). Council of Scientific and Industrial Research, New Delhi. P. 23.

Cos, P., Hermans, N., Bruyne, T., De Apers, S., Sindambiwe, J. S., Witvrouw, M., Clercq, E., De Berghe, D. V., Pieters, L., Vlietinck, A. J. (2002a). Antiviral activity of Rwandan medicinal plants against human immunodeficiency virus type-1 (HIV-1). Phytomedine, 9, 62-68. http://dx.doi.org/10.1078/0944-7113-00083

Cos, P., Hermans, N., Van Poel, B., De Bruyne, T., Apers, S., Sindambiwe, J. B., Berghe, D., Vanden, P. (2002b). Complement modulating activity of Rwandan medicinal plants. Phytomedicine, 9(1), 56-61. http://dx.doi.org/10.1078/0944-7113-00085

Cristina, S. F., Cristiane, H. B., Samanta, L. A., Maria, C. A. M. (2008). Effects of Pfaffia glomerata (Spreng) Pedersen Aqueous Extract on Healing Acetic Acid-induced Ulcers. International Journal of Phytomedicine, 51(4), 679-683. http://dx.doi.org/10.1590/S1516-89132008000400005

Dharmani, P., Mishra, P. K, Maurya, R., Chauhan, V. S., Palit, G. (2005). Allophylus serratus: A plant with potential anti-ulcerogenic activity. Joural of Ethnopharmacology, 99, 361-366. http://dx.doi.org/10.1016/j.jep.2005.01.011

Dharmani, P., \& Palit, G. (2006). Exploring Indian medicinal plants for antiulcer activity. Indian Journal of Pharmacology, 35, 95-99. http://dx.doi.org/10.4103/0253-7613.24613

Dominique, L. (1999). Bases fondamentales en physiologie. Hépato-Gastro. 6, 49-57.

Ebtehal, E. D., Hala, O., El-Mesallamy, Noha, M. A-Z., Mohamed, Z. G. (2010). The potential therapeutic effect of nitric oxide modulators in experimentally-induced gastric ulcers. Drug Discoveries and Therapeutic, 4(4), 276-284.

Ekpo, M., Mbagwu, H., Jackson, C., Eno, M., (2011). Antimicrobial and wound healing activities of Centrosema pubescences (Leguminosae). Jounal of physics and Chemistry of Solids, 1, 1-6.

Focho, D. A., Nkeng, E. A. P., Fonge, B. A., Fongod, A. N., Muh, C. N., Ndam, T. W., \& Afegenui, A. (2009). Diversity of plants used to treat respiratory diseases in Tubah, northwest region, Cameroon. African Journal of Pharmaceutical and Pharmacology, 3(11), 573-580.

Gyires, K. (2005). Gastric mucosal protection: from prostaglandins to gene-therapy. Current Medical Chemestry, 12(2), 203-215. http://dx.doi.org/10-2174/0929867053363478

Ishfaq, H., Ghulam, D., \& Farrukh, H. (2008). Nutritional and elemental analyses of some selected medicinal plants of the family Polygonaceae. Pakistan Journal of Botany, 40(6), 
2493-2502.

Joseph, B. S., Justin, R. S., (2011). A comparative study on various properties of five medicinally important plants. International Journal of Pharmacology, 7, 206-211. http://dx.doi.org/10-3923/ijp.2011.206.211

Lewis, D. A, \& Hanson, P. J. (1990). Anti-ulcer drugs of plant origin. In: Ellis, G.P., West, G.B.

(Eds.). Progress Medicinal Chemistry, 28, 201-231. http://dx.doi.org/10.1016/S0079-6468(08)70365-5

Malfertheiner, P., Chan, F. K. L., McColl, K. E. L. (2009). Peptic ulcer disease. The Lancet 374, 1449-1461. http://dx.doi.org/10-1016/S0140-6736(09)60938-7

Marivane, L., Jose, R. S., Luiz, C. K. J., Rivaldo, N., Sergio, F. (2011). Gastroprotective activity of hydroalcoholic extract obtained from the leaves of Brassica oleracea var. acephala DC in different animal models. Journal of Ethnopharmacology, 138, 503-507. http://dx.doi.org/10-1016/j.jep-2011.09.046

Muralidharan P., \& Srikanth, J. (2009). Antiulcer activity of Morinda Citrifolia Linn fruit extract. Journal of Science Research, 1(2), 345-352. http://dx.doi.org/10-3329/jsr.vli2.1625

Nguelefack, T. B., Catherine, B. F., Ateufack, G., Watcho, P., Tatsimo, S., Atsamo, A. D., Tane, P., Kamanyi, A. (2008). Anti-ulcerogenic properties of the aqueous and methanol extracts from the leaves of Solanum torvum Swartz (Solanaceae) in rats. Journal of Ethnopharmacology, 119, 135-140. http://dx.doi.org/10.1016/j.jep.2008.06.008

Nguelefack, T. B., Watcho, P., Nguelta, M. M., Wansi, S. L., Kamanyi, A., (2005). Effect of the methanol leaf extract of Alchornea cordifolia (Schum \& Thonn.) Muell. Arg. on different gastric ulcer models in rats. Cameroon Journal of Experimental Biology, 1, 54-56. http://dx.doi.org/10.4314/cajeb.v1i1.37928

Niranjan, S., Ranju, G., Uma, S. S., Narendra, S., Saumendu, D. R. (2011). Antiulceronic activity of Saussurea lappa root. International Journal of Pharmacy and life Science, 2(1), 516-520. http://dx.doi.org/2011.0976.7126

Oliveira, A. P., Santin, J. R., Lemos, M., Klein-Junior, L. C., Couto, A. G., Meyre da Silva Bittencourt, C., Cechinel-Filho, V., Faloni de Andrade, S. (2011). Gastroprotective activity of methanol extract and marrubiin obtained from leaves of Marrubium vulgare L. (Lamiaceae). Journal of Pharmacy and Pharmacology, 63, 1230-1237. http://dx.doi.org/: $10.1111 / \mathrm{j} .2042-7158.2011 .01321$

Pradhan, D., Panda, P. K., Tripathy, G., (2009). Wound healing activity of aqueous and methanolic bark extracts of Vernonia arborea Buch-Ham, in Wistar rats. Natural product Radiance, 8, 6-11.

Raju, D., Ilango, K., Chitra,V., Ashish, K. (2009). Evaluation of anti-ulcer activity of methanolic extract of Terminalia chebula fruits in experimental rats. Journal of Pharmaceutical Science Research, 1(3), 101-107. http://dx.doi.org/jpsr-pharmainfo.in 
Rates, S. M. (2001). Plants as source of drugs. Toxicology, 39, 603-613. http://dx.doi.org/S0041-0101 (00)00154-9

Sergio, F. A., Marivane, L., Eros C., Vania, F. N., Valdir, C. F., Rivaldo, N. (2007). Evaluation of the antiulcerogenic activity of Maytenus robusta (Celastraceae) in different experimental ulcer models. Journal of Ethnopharmacology, 113, 252-257. http://dx.doi.org/10-1016/j.jep-2007.06.002

Shay, J. P., Komorov, S. A., Fells, S. S., Meranze, D., Grunstein, M., \& Simpler, H. (1945). A simple method for the uniform production of gastric ulceration in the rat. Gastroenterology, 5, 43-61.

Shiramane, R. S., Chivde, B. V., Kamshetty, M., Birada K. V. (2011). Gastroprotective activity of ethanolic extract of Delonix regia flower in experimental induced ulcer in Wistar albinos rats. International Research Journal of pharmacy, 2(5), 234-238. http://dx.doi.org/irjponline.com

Sikiric, P., Seiwerth, S., Grabarevic, Z., Rucman, R., Petek, M., Jagic, V., Turkovic, B., Rotvic, I., Mise, S., Zoricic, I., Konjevoda, P., Perovic, D., Jurina, L., Separovic, J., Hanzevacki, M., Artukovic, B., Bratulic, M., Tisljar, M., Gjurasin, M., Miklic, P., Stancic-Rokotov, D., Slobodnajak, Z., Jelovac, N., \& Marovic, A. (1997). The influence of a novel pentadecapeptide, BPC 157, on N (G)-nitro-l-arginine methyl ester and 1-arginine effects on stomach mucosa integrity and blood pressure. European Journal of Pharmacology, 332, 23-33. www.ncbi.nlm.nih.gov/pubmed/9298922

Sreejayan, N., Rao, M. N. A. (1997). Nitric oxide scavenging by curcuminoids. Journal of $\begin{array}{llll}\text { Pharmacy and } \quad \text { Pharmacology, } & \text { 109-107. }\end{array}$ http://dx.doi.org/10.1111/j.2042-7158.1997.tb06761.x

Takagi, K., Okabe, S., Saziki, R. (1969). A new method for the production of chronic gastric ulcer in rat and the effect of several drops on its healing. Journal of Pharmacology, 19, 418-426.

Tan, P. V. \& Nyassa, B. (2000). Antiulcer compound from voacanga africana with possible histamine $\mathrm{H}_{2}$ receptor blocking activity. Phytomedicine, 7, 509-515. http://dx.doi.org/10-1016/S0944-7113(00)80037-9

Tan, P. V., Dimo, T., Dongo, E. (2000). Effect of methanol cyclohexane and methylene chloride extracts of Bidens pilosa on various gastric ulcer models in rats. Ethnopharmacology, 73, 415-421. http://dx.doi.org/10-1016/S0378-8741(00)00290-7

Tan, P. V., Nditafon, G. N., Yewah, M. P., Ayafor, J. F., Dimo, T. (1996). Eremomastax speciosa: Effect of the leaves aqueous extract on ulcer formation and gastric secretion in rats. Journal of Ethnopharmacology, 73, 139-142. http://dx.doi.org/10.1016/S0378-8741(96)01461-4

Tarnawski, A. (2005). Cellular and molecular mechanisms of gastrointestinal ulcer healing. Digestion and Disease Science, 50, 24-33. http://dx.doi.org/10.1007/s10620-005-2803-6

Thirunavukkarasu, P., Ramkuma, L., Ramanathan, T. (2009). Anti-ulcer Activity of Excoecaria agallocha back on NSAID-induced Gastric Ulcer in Albinos Rats. Global Journal 


\section{Macrothink}

of Pharmacology, 3(3), 123-126. www.idosi.org/gjp/3(3)09/2

Tulassay, Z, \& Hersnzenyi, L. (2010). Gastric mucosal defense and cytoprotection. Best Practice Research Clinical. Gastroenterology, 24, 99-108. http://dx.doi.org/10.1016/j.bpg.2010.02.006

Umamaheswari, M., Asokkumar, K., Rathidevi, R., Sivashanmugam, A. T., Subhadradevi, V., Ravi, T. K. (2006). Antiulcer and in vitro anti-oxidant activities of Jaminun grandiflorum L. Journal of Ethnopharmacology, 6, 464-470. http://dx.doi.org/10-1016/j.jep.2006.10.017

\section{Copyright Disclaimer}

Copyright for this article is retained by the author(s), with first publication rights granted to the journal.

This is an open-access article distributed under the terms and conditions of the Creative Commons Attribution license (http://creativecommons.org/licenses/by/3.0/). 